\title{
“E-GOVERNMENT PORTAL" AND E-SERVICES IN TURKEY
}

\author{
Yucel Ogurlu*
}

\begin{abstract}
Likewise in other developed countries, E-government in public administration in Turkey has been introduced with an aim to improve state's administrative efficiency and competency. These modern administrative approaches and opportunities from technological innovation will inevitably provide high quality services and participation at all levels of the public administration. For this purpose, Turkey established e-Government portal, (e-Devlet Kapisi) a virtual structure which enables access to digital public services. The aim of the e-Government portal is to provide its users service through only one website and safe digital media. Since accessing the services through only one website makes access easier, high speed and system security are required too. The security system requires identity verification, password and e-Signature. Turkey has successfully implemented the e-government project and with sub-projects such as the National Judiciary Information System Turkey received many international awards. Other than public services similar to e-hospital, e-municipality and e-tender, other social service institutions can also use same administrative approach as to make their service available. Therefore, this paper shortly analyzes technical and legal challenges and technical, administrative and legal solutions of the e-Government portal.
\end{abstract}

Keywords: E-Government; E-signature; E-Service; Digital Public Service and Electronic Service.

\section{Introduction}

Technological developments on the eve of the twentieth century reshaped almost every aspect of human life and significantly influenced almost every academic discipline. Information and communication technologies restructured not only the way we understand the concept of government in classical terms, but also it changed the way governments and public administrations operated and functioned. Internet, perceived as one of the major achievements of the information revolution, singled out itself as the most important tool for restructuring the public administration due its high potential in optimization, efficiency, productivity, accountability and transparency.

Public administration changes fostered by the information and communication revolution led to the transformation into new forms of government usually referred as e-government, electronic or digital government. The concept of e-government could be seen as ambiguous; however generally it is defined as the use of technology as a tool to deliver government services to its customers which can be citizens, businesses, other 
governments, NGOs, etc. (Means and Schneider in Yildiz, 2002 pp. 41-57). Today, e-government encompasses a wide range of meanings from policies related to the development of information structures to the measures for the improvement of the public administration's functions (Linz, 1996).

One of the major aspects of e-government is how to bring customers (citizens, business, other governments and NGOs) closer to their governments aiming at simplifying procedures but keeping the privacy and security of its clients. Therefore, there are four main, very broad, categories or models which e-government encompass that represent the scope of e-government: Government-to-Citizens (G2C), Government-to-Business (G2B), Government-to-Government (G2G) and Government-to-NGO (G2N).

E-government, contrary to tradition governments, aims at reducing and minimizing the bureaucracy in order to ensure that governments functions more accurately, efficiently and transparently. In the e-government system there is no mediator between citizens/ business and information, that enables quick flow of information, reduced workflow and reduces the error rates (Stamoulis, 2001). One of the major provisions of e-government is e-services which represent its ultimate goal, but not aiming to replace the traditional services. Rather, they are perceived as complementary aiming at reducing the lines and providing the services 24 hours per day, seven days in a week.

According to the United Nations e-Government Survey 2012 five world leading countries in implementation of e-government initiatives are Republic of Korea, the Netherlands, United Kingdom, Denmark and United States, with the e-government development index higher than 0.85 .

\begin{tabular}{llllll} 
Table 1.1. World e-government leaders & (Very High EGDI) in 2014 & \\
& & 2014 & 2014 & 2012 & Chang \\
Country & Region & EGDI & Rank & Rank & (201: \\
\hline Republic of Korea & Asia & 0.9462 & 1 & 1 & \\
\hline Australia & Oceania & 0.9103 & 2 & 12 & $\uparrow$ \\
\hline Singapore & Asia & 0.9076 & 3 & 10 & $\uparrow$ \\
\hline France & Europe & 0.8938 & 4 & 6 & $\uparrow$ \\
\hline Netherlands & Europe & 0.8897 & 5 & 2 & $\downarrow$ \\
\hline Japan & Asia & 0.8874 & 6 & 18 & $\uparrow$ \\
\hline United States of America & Americas & 0.8748 & 7 & 5 & $\downarrow$ \\
\hline United Kingdom & Europe & 0.8695 & 8 & 3 & $\downarrow$ \\
\hline New Zealand & Oceania & 0.8644 & 9 & 13 & $\uparrow$ \\
\hline Finland & Europe & 0.8449 & 10 & 9 & $\downarrow$ \\
\hline Canada & Americas & 0.8418 & 11 & 11 & $\uparrow$ \\
\hline Spain & Europe & 0.8410 & 12 & 23 & $\uparrow$ \\
\hline Norway & Europe & 0.8357 & 13 & 8 & $\downarrow$ \\
\hline Sweden & Europe & 0.8225 & 14 & 7 & $\downarrow$ \\
\hline Estonia & Europe & 0.8180 & 15 & 20 & $\uparrow$ \\
\hline Denmark & Europe & 0.8162 & 16 & 4 & $\downarrow$ \\
\hline Israel & Asia & 0.8162 & 17 & 16 & $\downarrow$ \\
\hline Bahrain & Asia & 0.8089 & 18 & 36 & $\uparrow$ \\
\hline Iceland & Europe & 0.7970 & 19 & 22 & $\uparrow$ \\
\hline Austria & Europe & 0.7912 & 20 & 21 & $\uparrow$ \\
\hline Germany & Europe & 0.7864 & 21 & 17 & $\downarrow$ \\
\hline & & & & & \\
\hline
\end{tabular}

Source: UN e-Government Survey 2014. 


\section{E-government in Turkey}

Development of e-Government in Turkey started in early 1990s with the establishment of Information Society and knowledge-based economy (Sayan, et al. 2004). The purpose of Information Society was to increase Turkey's competiveness focusing on innovation, science and technology and strengthening ICT capacities and capabilities in Turkey (OECD, 2007).

The first phase was characterized with simple application of ICT techonologies usually providing basic information to citizens via official websites that could be considreder only as electronic user manuals of institution that countinued to provide services in traditional manner. Late 1990s and by the begining of 2000s mainly were characterized by the initivatives and developmental plans for implementation of e-government services which led to broad discussion of governement, academic, NGO, business and public sector.

In the past several years' Turkish officials argued that it is necessary to develop so-called Prime Ministry Management Information Center in order to provide services and information through only one website on the model of USA Firstgov Portal (Fletcher Patricia and Torok, 2003, pp. 268-281). Those pioneers of e-Administration in Turkey were arguing that without such an integrated service stipulation, e-Administration would appear as isolated from each other, independent and scattered. Therefore, because of the complexity of this structure, public service users refrained from using $e$-Administration services and relayed more on classical procedures. In this regard, there was always a need for integrating portal throughout the country.

The Prime Ministry Directorate General for Personel and Policies initiated the establishment of the Board of Technical Public Network formed (Genelge, 1998). In 2002, the Board of Technical Public Network, within the framework of e-Europe and $e$-Turkey, managed to transform traditional system of government to $e$-Government. New e-Government model aimed to provide "efficient, transparent, fast and continuous" services by using information and communication technology. Then, in order to comply with the needs of information society, e-Government also aimed to incorporate statecitizen relationships into digital media by establishing $e$-Institutions and "Government e-Portal"' (State Planning Organization, 2002, p. 1).

There are many works on the implementation of $e$-Government (Ogurlu, 2010); however for the sake of a brief illustration the "Ninth Development Plan" (2007-2013) summarized e-Government implementation as follows:

MERNIS project is information system which keeps citizen identity information based on single number and these information are shared with other public institutions. Tax and customs transactions procedures 
are significantly introduced in electronic environment and its usage is continuously expanding. National Jurisdiction Network Project and e-declaration that include social security proceedings have been implemented. Budget Management Information System that is supporting budget preparation and operations is being efficiently implemented by public administrations. All legal and administrative infrastructures for $e$-Signature have been created and it is already in public use. E-Government portal that was introduced in 2005 continues its efforts towards integrating the service delivery to citizen from single point (pp. 51-52).

In the aforementioned Development Plan, e-Government basic infrastructure was envisioned. Actually, there are views that since 2005 initial steps towards e-Government portal and further gradual developments provided "integrated service delivery" from one internet point. In this regard, according to MERNIS Project,

a single number, based on citizens' identity information and information held information system created to be shared with other public institutions started. A tax and customs operation with a large extent is presented and the use of electronic media has become widespread. $e$-Declaration applications including The National Judiciary Network Project and the social insurance transactions, have been carried out. The Budget Management Information System that supports process of budget preparation and operational support, has been using by public administrations effectively. For the use of $e$-signature in the public sector, legal and administrative substructure were created and the application was begun (Ninth Development Plan (2007-2013), 2006, p. 52).

According to the survey result, www.turkiye.gov.tr was adopted as yet another name for the portal that will be created.

\section{E-Government Digital Public Service Opportunities}

Users of digital public services should possess "password, electronic signature and mobile electronic signature," as to verify their identity. Since this information is accessible only to people who can provide identity verification, they are completely safe. Then, other most important advantages of $e$-Government and digital public services are user-friendly applications and confidentiality. In this regard, for the identification of a particular user a variety of means could be used from credit cards to password, e-signature and m-signature (mobile signature) (Ninth Development Plan (2007-2013), 2006, p. 52). It is worth mentioning that this model, that provides services and infrastructure through $e$-Government, is familiar to the users of other countries, especially neighboring countries (Devletin Kisayolu-turkiye.gov.tr). 
At this moment, $e$-Government home portal (e-Government portal) is a system which gives access to digital public services through a single web site. E-Government portal aims to provide the services to the public through a single address and in a safe digital environment. In order to approach other services, single identification confirmation is enough. In the Article 2, paragraph (i) of the "Draft of the Law on e-Government and Information Society" prepared by the Prime Minister, "e-Government portal" is defined as follows: "The e-Government portal: information system provides users a single access point to services of e-government public institutions and organizations" (Devletin Kisayolu-turkiye.gov.tr).

In the twenty-first article of the Draft titled e-Government Portal, it is planned to give a more superior regulation:

(1) E-Government portal, as common e-government service, is regulated within the guidance and supervision of the Agency. The mission, authority and responsibilities of manager of e-Government portal are determinate by regulations prepared by Agency.

(2) Services of e-Government portal are offered in the way that users can easily benefit from it; it is simple and functional.

(3) Agency gives priority to public institutions and organizations that take place in e-Government Commitment Service and it sets services through e-Government portal. The services will be integrated into $e$-government portal and indicated separately in e-government service commitment of related institution. The integration of established services to $e$-government portal is provided by manager of e-government portal and institutions providing the related service.

(4) While providing supplement to projects, the Agency takes into consideration studies of integration to $e$-government portal. Agency has the authority to take the necessary measures in order to complete all activities regarding the integration of public services into e-Government without the delay.

(5) The content presented through e-Government Portal and service-related changes are at the same time forwarded to the operator of e-Government Portal to be published by the institution responsible for the content. The institution providing given content and e-government portal manager are both responsible for up-dating the information.

(6) In e-government portal identity verification is done at various levels. For which services and at what level identity verification will be made is determined by responsible institution according to principles and procedures published by the Agency.

According to the Community Information Strategy (2006) it is determined that change in 'citizen oriented' public services will be redesigned and during implementation of this strategy, as the main principle, public service and "user satisfaction" with work 
processes will be considered. Here, it will be useful as well, to set a goal defined by strategy:

"The primary aim of the service in conversion is not to move data to electronic location without the improvement of current work processes, but redesigning it by combining and simplifying it according to users' needs and in the way that is efficient, fast, continuous, transparent, safe and integrated. In order to simplify access of the citizens and businesses to electronic public services, access to these services from single point and different platforms will be secured (Bilgi Toplumu Stratejisi Belgesi (2006-2010)).

\section{E-government Portal and Digital Public Services}

E-government portal gives opportunity to public institutions to share information and documents with each other. Public institutions and public services of the organizations and all those associated with these services are opened to share "correct and update information" ("Devletin Kisayolu-turkiye.gov.tr"). It is easy to make payment transaction for digital public services (tax, fees, etc.) through "payment unit service" of "e-government portal" (e-government home portal). This step meets an important precondition in running the $e$-government and it is a basic step for carrying out the financial work. On this site, with cooperation of totally 17 institutions, 122 services and facilities have been offered.

The services provided through $e$-government portal can be grouped according to their type in following six titles: information services, digital public services, payment systems, shortest way to access institutions and organizations, up-dated information and notices and messages from institutions to the public (Information Society Strategy Document (2006-2010), p. 29).

There are different information and articles on services that are given by e-government portal and home portal links in Turkey.

1. Individuals and society: Access to information on topics such are homeless children, social assistance and solidarity, female gender issues, housing and gambling games.

2. Legal procedures, rights and defense: law measures, voter procedures, protection of the consumers, system of address registration, access to public notaries, application and required information.

3. Birth: Information and services such as birth registration, prenatal and post natal permits, maternal and infant health.

4. Military service and mobilization: Such procedures are military operation, officer ranks and reserve military, abroad or payment in foreign currency for military service.

5. Education: Kindergarten, primary and secondary schools, distance learning 
education, higher education and services provided by Student Selection and Placement Center.

6. Traffic: Traffic safety, motor vehicle operations, driving license procedures, highway control.

7. Health: Family health, public health, oral and dental health, nutrition information and scheduling appointments at hospital.

8. Citizens with disabilities: Health, education, employment, social rights and services, home-care services.

9. Turkish citizens living abroad: Information and services such as $e$-Consulate, population registrations, diploma equivalency, military service and marriage.

10. Art, culture and sport: Information and services such as cultural heritage, cultural activities, theaters, festivals, sport activities, fairs and local activities.

11. Job and career: Social Security Institution services for employees.

12. Family: Information and application forms for marriage, family health, population registration, children and teenagers and children rights.

13. Travel and tourism: General information about Turkey, types of tourism in Turkey, service for Turkish citizens living abroad, information about railway and highway transportation.

\section{E-Government Portal Institutional Usage}

Besides providing informative services such as weather forecast Turkish State Meteorological Service also interactively downloads forms, keeps tracks of documents and follows their online phases or makes payments by filling out the declaration statements. It is a remarkable fact that, just like UYAP Portal (National Judiciary Information System), Ministry of Justice also supports a trial service that uses the public services. Similar forms of e-Government portal services are provided by the Ministry of labor and social security, Turkish National Police, Revenue administration department - $e$-Tax Registration Certificate Inquiry, Turkish Employment Agency (ISŞ-KUR), General Directorate of Coastal Safety, The Ministry of Finance, Ministry of Defense, General Directorate of Civil Registration and Nationality, Post Office, The Ministry of Health, The Ministry of Industry and Commerce, General Directorate of Civil Aviation, General Directorate of Land Registry and Cadastre, Turkish State Railways and Ministry of Transportation.

When designing E-government portal, people with disabilities were not forgotten and system was made easy for them to use. Recommended by European Union and accepted in all European countries, easier access for disabled people to public digital services was taken into consideration while designing the portal. It should be noted that it is not possible to make successful parallel infrastructure expansion and advertisement on this matter. Being able to apprehend reasonable and realizable goals is also important for later goals and plans. 
One of the goals for the year of 2010, as it is presented in the Information Community Strategy Document (2006-2010), is 'people oriented service transformation' that uses information and communication technology to present public services in digital media in effective way. While doing this, we need to have in mind those who benefit from such preferences and requirements, since the goal is to make easier approach to digital services, increasing its usage rate and increasing the satisfaction of those using the services. In the strategy report planned till the year of 2010, it has been emphasized that these basic goals should be achieved:

- Increasing the number of public services offered in digital media and raising their level of development.

- Increasing the use of public services presented in digital media,

- Increasing the level of satisfaction of those benefiting from the use of public services offered in digital media services (Bilgi Toplumu Stratejisi Belgesi (20062010).

In the above mentioned document, among the other goals that will be carefully considered by the year of 2010 , there is realization of $70 \%$ of public services that were feasible to be offered digitally have been provided, improvement of presentations" "level of development" and "Benefit-cost rates". Priority will be given to "high income services" and resources that are intensively and efficiently used (Information Society Strategy Document (2006-2010) p. 30).

According to data gathered from Under-secretariat of State Planning Organization, in the annexed Action Plan and in Turkey's Community Information Strategy that is planned to be completed by the year of 2010, at the beginning of 2009 only 4 out of 74 planned activities were used effectively, showing the necessitate to start with more pragmatic plans when it comes to their realization (Bilgi Toplumu Stratejisi Eylem Plan1, 2006; “e-Devlet ve Bilgi Toplumu Kanun Tasarısı Taslağı"nın Genel Gerekçesi, 2009). In the year of 2010, it is expected that one out of three public service transactions made by citizens would be conducted through electronic ways, and in 2010 consumers' satisfaction shall rise to $80 \%$ (Information Society Strategy Document (2006-2010), 2006, p. 30).

\section{Conclusion}

Digital public services and its preparatory digital facilities are related to its quality. It is necessary to consider digital public service as services that has benefited from classic public services and one that facilitates services. New possibilities and opportunities provided by information and communication technologies determinate natural border that will be provided through digital services environment. Certain public services are comprised of steps such as informing, downloading a form, filling and exercising a form. Since some actions require accurate and executive steps, it is not possible for these services to be provided by digital environment. Public services such as garbage collection, 
physical intervention to provide public order, and medical examination are not possible to be transmitted through digital environment. Even in classical public services such as safety, health and education, information and communication technology possibilities and opportunities are considered an auxiliary element. Some public services can be completely provided through digital environment. It is impossible to imagine and predict in advance what kind of service models will appear in the future. Mobile phones and security cameras we watched in science fiction movies, which were made 20 years ago, became part of our lives today, so it is difficult to imagine new models we are to see in the future. Services such as radio and TV broadcasting, communication services, telephone and fax, education, jurisdiction and preventive medicine are most likely to be transmitted to digital environment in the near future. The classic education and court activities are gradually beginning to be transmitted to distance learning education and $e$-courts. It has also become a support element for the public services which are not suitable to provide MOBESE cameras in security, computer aided planner statistics program in collecting garbage, medical services, data collection, storage, monitoring, evaluating and keeping statistics, in digital environment. Besides this, looking from the administration law point of view, e-Administration eased the job of municipality services such as subscription, objection, filling out statements, paying taxes, applications for administration and application tracking.

Tens of countries started to use e-administration in period before Turkey but they are still looking for solutions related to $e$-Administration problems. Within the framework of this problem and solution efforts, digital public services should be integrated throughout the country; responsibilities about the establishment, operation and management of $e$-Administration should be undertaken; gained momentum should be maintained; focus of the program should not be diverted; the aim of drawn plan and strategy should be preserved; cooperation between public service users and administration comprising $e$-Administration parties should be established; continuous renewed technical components should be introduced to service users and public staff.

\section{References}

Behire Esra Çayhan, 2008. "Implementing e-Government in Turkey: A Comparison of Online Public Service Delivery in Turkey and the European Union", The Electronic Journal on Information Systems in Developing Countries. 35, 8, 1-11.

“Bilgi Toplumu Stratejisi Belgesi.” (2006-2010), RG.28.07.2006, S.: 26242, s.28.

"Devletin Kısayolu-turkiye.gov.tr”, (çevrimiçi); Türkiye'de E-Devlet Çerçevesinde İdare Hukuku Anlaylşında De ğişim

"Devletin Kisayolu-turkiye.gov.tr"

https:/www.turkiye.gov.tr/portal/dt?channel=bilgilendirme\&bilgilendirme.bilgiTipi=sikcaSorulanlar. ET.28.03.2009.

Diamond Fletcher Patricia; Torok Andrew G., 2003. "Creating the front door to government: A case study

Epiphany: Journal of Transdisciplinary Studies, Vol. 7. No. 2, (2014) (C Faculty of Arts and Social Sciences 
of the Firstgov portal," Library Trends, Vol. 52, No. 2, pp. 268-281.

Genelge. 1998. Republic of Turkey Prime Ministry Directorate General for Personel and Policies, Number: B.02.0.PPG.0.12-320-04993.

Ibrahim Akman, Ali Yazici, Alok Mishra, Ali Arifoglu. 2005. "E-Government: A global view and an empirical evaluation of some attributes of citizens", Government Information Quaterly, 20.

Information Society Strategy Document (2006-2010), RG.28.07.2006, Number: 26242.

"Ninth Development Plan" (2007-2013), dated on 1 st July, 2006 Mükerrer Official Gazzette (Number.: 26215).

OECD (2007), OECD e-Government Studies: Turkey 2007, OECD Publishing.

Ogurlu, Yücel. 2010. “İdare Hukukunda “e-Devlet” Dönüşümü ve Dijitalleşen Kamu Hizmeti”, Oniki Levha Publications, Istanbul.

State Planning Organization, "e-Devlet'e Geçiş Sürecinde KamuNet Çalışmaları," KamuNet Technical Board Passingto Information Age State, State Planning Organization, Management Information Center Department (KamuNet Technical Board Chairmanship), November 2002.

Türksel K. Bensghir and Mete Yildiz. 2001-2002. “Perceptions of E-government in Turkey”, Turkish Public Administration Annual, Vol. 27-28, p. 41-57.

UN e-Government Survey. 2014 UN Publishing, Available at: http://unpan3.un.org/egovkb/Portals/egovkb/ Documents/un/2014-Survey/E-Gov_Complete_Survey-2014.pdf

D. Stamoulis, D. Gouscos, P. Georgiadis and D. Martakos, 2001 "Revisiting public information management for effective e-government services", Information Management and Computer Security, Vol.9 No.4, MCB University Press, pp. 146-153. 